\title{
Analysis on Current Ideological Security in Universities and Its Countermeasures
}

\author{
Chenchen Huang \\ Wuhan University of Science and Technology \\ Wuhan, China
}

\begin{abstract}
Ideological security in universities is an important part of national ideological security. The ideological security in universities concerns the guiding role of Marxism in universities, the training of builders and successors of socialist cause with Chinese characteristics, the lasting political stability of the party's cause as well as the great rejuvenation of Chinese nation. However, under the influence of challenges at home and abroad, the negative effects of network media and diversified ideology and culture, the ideological security in universities is not optimistic. Therefore, for the maintenance of ideological security in universities, we should adhere to the concept of "cultivating people by all members in society, in the whole process and all directions", integrate the ideological work in teaching, scientific research, management and service and unite the strength and effective resources to reinforce the ideological security in universities of China.
\end{abstract}

Keywords—universities; ideological security; path

\section{INTRODUCTION}

On the National Conference of Propaganda and Ideological Work in 2013, General Secretary Xi Jinping stressed "Ideological work is crucial for the Party", "The ideological work concerns the future of the party, lasting political stability of the country and national cohesion and solidarity."[1] Universities provide intensive and new knowledge and ideas as well as serve as work base of ideology. How about the ideological status in universities at present? What factors affect the ideological security in universities? How to construct the ideological security? On the basis of these questions, the research group investigates 32 universities on site and on the internet.

\section{NECESSITY TO STRENGTHEN THE IDEOLOGICAL SECURITY CONSTRUCTION IN UNIVERSITIES}

In January 2015, the Opinions on Further Strengthening and Improving the Ideological Publicity Work of Universities in the New Situation issued by General Office of the CPC Central Committee and General Office of the State Council stated: Ideological work is vitally important for the party and nation. As forward position of ideology work, universities are responsible for learning, researching and propagating Marxism, cultivating and carrying forward socialist core values and providing talents and intellectual support, so as to realize the China Dream of the great rejuvenation of Chinese nation. It clearly shows the importance of ideological security in universities.

\section{A. Ideological Security in Universities Is An Important Part of National Ideological Security}

National ideological security refers to the relatively stable state that the dominant political ideology of a country is free from infringement. It is an important part of national security. Marx addresses, "The disintegration of ideology can ruin the whole era powerfully on the basis of investigation on concept." [2] The party and state leaders have been paying high attention to ideological security. General Secretary $\mathrm{Xi}$ Jinping profoundly states, "The collapse of a regime starts from ideological field. Political unrest and regime change may happen overnight, but it needs long time to evolve the thought Once the ideological defensive line is broken, other defensive lines cannot remain. We must firmly hold the hegemony, administration authority and speaking right, or irretrievable historical mistake will be made." [3] Currently, under the historical background that ideology and culture exchange and conflict, different institutional models and values compete fiercely, universities have become the distributing center of ethos, the important place for various ideologies to compete, the battle position for Marxism research and the main battlefield to cultivate builders and successors for socialism with Chinese characteristics. The ideological security construction in universities is important for the flag and road, and the practical needs to maintain national ideological security.

\section{B. Ideological Security in Universities Is the Political Guarantee of School Running in Socialist Direction}

In the educational reform and the development of universities, we must answer the basic question "What kind of university do we need to run and how to run it very well?" On the Twenty-third National Party Building Work Conference in University, General Secretary $\mathrm{Xi}$ Jinping stresses the university construction shall adhere to socialism with Chinese characteristics. Nowadays, higher education of countries around the world exists under specific productive relations and cannot do without social system and meeting social needs. "University in western countries is the highest position for bourgeoisie to exercise cultural leading right and important part of ideological state apparatuses." [4] For universities in our country, the effect of ideology construction concerns not only the development direction of university in China but also 
the future of China. If universities cannot persist in the leading position of socialist mainstream ideology, they are easily used by western developed capitalist countries to advocate their ideology. On the conference learning and implementing the spirit of Opinions on Further Strengthening and Improving the Ideological Publicity Work of Universities in the New Situation, Yuan Guiren points out, "Chinese universities stick to socialism. Reinforcement of ideological security construction in universities is the political guarantee of socialist orientation in running universities.

\section{Ideological Security in Universities Is the Inherent Requirement to Train Qualified Socialist Talents}

University plays a role in teaching and scientific research, social service and cultural inheritance, but the foremost is talent training. The Eighteenth National Congress of the CPC takes morality education as the basic task of education, which is the profound interpretation of the nature of education and the scientific explanation of the fundamental question "what kind of people will be trained and how to train people" for universities. Young people are the future and hope of the nation. The country will be prosperous and strong if young people become talents. When investigating Peking University, General Secretary Xi Jinping tells young people to "correctly take the first step of life", because the value orientation of young people decides that of the whole society in the future.

At present, young people in the contemporary era don't need to fight like the older generation of revolutionaries but suffer from material and spiritual temptation. It is a significant and urgent political task endowed by the era for universities to seize historic opportunity, meet actual challenges and be brave in innovate in the globalization tide, push and lead socialist mainstream ideology and train a new generation of qualified builders and successors of socialist cause, leading them to realize life value in the practice of achieving "Two Centenary Goals" and the great rejuvenation of Chinese nation.

\section{THE URGENCY OF STRENGTHENING THE IDEOLOGICAL SECURITY CONSTRUCTION IN UNIVERSITIES}

The research group has carried out investigation and interview on the Ideological Security Status in Universities under New Situation in 32 universities. 1,800 paper questionnaires and online questionnaires are distributed, with valid questionnaires of 1,614, effective rate of $89.7 \%$, involving more than 70 personal and collective interviews. According to the investigation, on one hand, the ideological status in universities of China is good under control; on the other hand, our country is in the critical period to finish building a moderately prosperous society, deepen reform, advance the law-based governance of China and strengthen Party self-discipline. The social ideology is unprecedented complex and various ethos floods. The ideological security status in universities is not optimistic. Problems are shown as follows:

\section{A. Marxism Belief of Some Teachers and Students Weakens}

Belief is important to balance ideological orientation. In regard to the question "what is your belief?", $41 \%$ of teachers and students think "the values of freedom, equality, fairness and justice" are their belief; $20.1 \%$ of interviewees "take pragmatism as their belief"; there are only $19.6 \%$ taking "Marxism and communism" as belief; 3.8\% take religion as belief; $11 \%$ of people don't have belief.

Besides, in the question "how do you think about Marxism?", $62.5 \%$ of interviewees think "Marxism is still the guiding ideology that we must adhere to in the long run"; however still $11 \%$ of interviewees think it is "only a theoretical branch" without practical significance; 3\% of interviewees address "it has been outdated". People that "don't know what Marxism is" account for $20.6 \%$. It shows Marxism belief has lost its charm and cohesion under the challenges of the era and reality. The "belief crisis" of Marxism has appeared among teachers and students of universities.

\section{B. The Assimilation of Western Social Thoughts Appears}

1) Western constitutional democracy thought affects the identification of teachers and students for socialist system: In the question "what's your opinion on advocating constitutional democracy?", more than 55\% think "no necessary to make a fuss" and "it is feasible"; only $16.9 \%$ resist determinedly. With respect to westernization, less than $50 \%$ "disagree", implement "separation of the three powers" and "multi-party system". More alarming, when asked "what's your opinion on the 'military nationalization' in our country?", 43.7\% "advocate" while 32.6\% "disapprove"; when asked "what's your opinion on 'general election' in our country?", $52.9 \%$ "agree", far more than $30.7 \%$ "disagree". It shows under the long-term influence of western ideological concepts like "democracy, freedom, equality, human rights and reason", the political identification and political value of some university teachers and students become divided.

2) The ethos of historical nihilism prevents university teachers and students from having correct conception of history: Historical nihilism is to make history nothing. In the name of reflecting on the history, the people advocating historical nihilism distort the real intention of "emancipating the mind", present classics humorously, replace correct statement with absurd and violate historical tradition through catching at shadow and nonexistent stories. At present, the ideological trend of historical nihilism has had serious adverse effects on universities.

In the question "some people think the objective effect of social improvement is better than that of radical revolution. The radical revolution of China in modern times hinders the development and progress of China. What's your attitude towards this statement?", only $6.1 \%$ and $18.8 \%$ "totally agree" and "totally disagree" respectively. $56 \%$ of interviewees think "it makes sense". It shows the opinion "say goodbye to revolution and praise improvement" prevails in universities currently.

In the question "some people think without the revolution of the Communist Party, China may develop better now if the Nationalist Party were in power developed capitalism. Do you agree with this opinion?", $41.3 \%$ "disagree" while $28.4 \%$ and 
$27.6 \%$ think "it is reasonable" and "it is hard to say" respectively. It shows most interviewees have correct understanding for the nature and historical function of Chinese Communist Party, but some people still doubt even deny socialist road. The basic historical recognition of some university teachers and students has been influenced by historical nihilism.

3) The deceptive effect of ideological trend of civil society in western countries has revealed: In recent years, the ideological trend of "civil society" in ideological field surges. Western countries like America intervening political society in China and domestic social forces attempting to realize political purpose in the name of "civil society" play the role of adding fuel to the fire. The purpose of ideological trend of civil society is to realize the so-called western modernization in Chinese society. In other words, it brings western system and social formation in China and drives Chinese politics to turn to western democratic system, realizing the so-called modernization transformation. Some university teachers and students cannot see through the political intention but believe "civil society" can promote political and social reforms in our country.

Only $4.1 \%$ of interviewees think civil society is opposed to the government, while $81.2 \%$ think on the contrary; more than $40 \%$ think civil society organization helps to safeguard civic rights; almost $40 \%$ think civil society organization plays significant role in supervising the government; unexpectedly, $64.7 \%$ think civil society should be encouraged in our country. It shows most teachers and students cannot make out the essence of western social democracy and the danger hidden under the veil of "civil society". Meanwhile, the deceptive effect of civil society in western countries has challenged the authority of the party and government among university teachers and students.

\section{The Responsibility of Party Committee in Some Universities Becomes Empty Talk in Their Ideological Work}

Party committees in universities lead the ideology work. However, according to the interview results, some party committees did not learn, investigate and think about the ideology work in depth, refusing to take precautions, work in advance and take the initiative. Furthermore, they "say it is important, but secondary in doing and insignificant when they are busy", severely weakening the effect of ideology work in universities, as shown in the following two aspects:

1) The importance of ideological work as chief responsibility of party committee in university is weakened: Correct understanding serves as the basis of conscious action. The understanding and attitudes toward ideology work directly concern its quality and effect. At present, although objective difficulties restrict the ideology work in universities, insufficient subjective cognizance is the root cause. A few leading cadres don't want to, don't know how to and don't dare to implement ideology work. Moreover, some universities let ideology work opposite to other school affairs, excluding ideological security from campus security, not aware of "grasping thought leadership is foremost in leadership", [5] focusing on specific affairs like fund raising, student enrollment, improvement of school conditions and expansion of school size, consciously or unconsciously neglecting even giving up the leadership and initiative in ideology work.

2) Party committees in some universities don't regulate ideology strictly: Firstly, the responsibility is unclear. Most universities emphasize "joint management" instead of "division of labor". Tasks and responsibilities of party committee, propaganda department, school league committee, student affair department, primary party organization, class advisor and counselor are unclear. Sometimes they don't know what to do, or manage chaotically and don't manage.

Secondly, the investigation is not implemented. Ideology work is a long-term daily work. At present, universities are short of systems and measures to inspect it. Because clear corresponding relation does not form between college level and school level, party committees only pay attention to propaganda department and know about primary party organization through year-end summary.

Thirdly, the inspection and appraisal are unsound. It is difficult to use precise data to evaluate because ideology work exerts a subtle influence. Generally speaking, universities lack in sound inspection and appraisal mechanism. Awards and quantity of paper serve as the criteria of inspection and appraisal, difficult to show the overall effect of ideology work. Corresponding mechanism lacks in universities to dispose teachers unsuitable for ideology work proved by the practice and realize job transfer.

Fourthly, network construction and management are unsound. The function of network is incomplete. Marxist classics cannot be read online on campus website of most universities. The internal educational function of network is discounted; the publicity and its sphere are restricted because there are few links outside the campus website; it has small quantity of information and low click rate, lacking interactivity.

\section{ThOUGHT TO STRENGTHEN THE IDEOLOGICAL SECURITY CONSTRUCTION IN UNIVERSITIES AND ITS COUNTERMEASURES}

Ideology work in universities is an important part of ideology work of the whole party. The ideological security construction in universities concerns the guiding role of Marxism in universities, the training of builders and successors of socialist cause with Chinese characteristics, the lasting political stability of the party's cause as well as the great rejuvenation of Chinese nation. Universities should carry out ideology work, knowing their responsibility in defend Chinese territory, responsible for any matter concerned with the post, and performing duties whole-heartedly.

\section{A. Party Committee in Universities Should Implement Main Responsibility System and Firmly Grasp Three Rights \\ In the Opinions on Further Strengthening and Improving the Ideological Publicity Work of Universities in the New}


Situation issued by General Office of the CPC Central Committee and General Office of the State Council, it is clearly required that "party committee in universities should strengthen political and leadership responsibility. Secretary of the party committee and the principal should take a clear-cut stand in ideology work." It reflects the main responsibility of party committee in ideology work. The performance of party committee's duty is political requirement for ideology construction. Therefore, to strengthen ideological security construction, party committee in universities must plan strategy based on the current situation in accordance with the demands of the time and practical development, firmly holding the rights of leadership, management and speaking of the party in ideology work of universities.

1) Firmly hold the right of leadership in ideology work: As the core of leadership in ideology work, party committee in universities must unceasingly strengthen political perspicacity and judgment ability to resist wrong trends of thought. Main leaders in school should distinguish major issues of principle and take the initiative to fight for right of leadership in guiding the public opinion reasonably.

2) Firmly hold the right of management in ideology work: Universities should make "two classes" take effect, namely the high unity of school teaching and social practice, becoming proactive in ideology work. More important, operation mechanisms of ideology work with online and offline interaction should be built to lead public opinions spreading positive energy.

3) Firmly hold the speaking right in ideology work: The ideology work should adapt to the new normal and learn to use new technology and means to reinforce initiative and predictability, improving the level and quality of work. Moreover, seize the opportunity timely, solve problems of "when to say", "what to say" and "how to say", to further guide ethos.

Strategic thinking, bottom-line thinking, system thinking and legal thinking must be established firmly to strengthen ideological security construction and implement the main responsibility system of party committee, avoiding situations "cannot use new method, dare not to use tough method, and old and soft method are useless".

\section{B. Universities Should Build IdeologicalWork Team and Reinforce the Cohesive Force of IdeologicalWork}

As a system engineering, ideology construction in universities should adhere to the idea of "cultivating people by all members in society, in the whole process and all directions", integrate it in teaching, scientific research, management and service. Effective resources should be integrated to continuously improve the ability and level in ideology construction, construct ideology work team and create new pattern of ideology construction in universities.

1) Build teaching body of ideological and political theory course with unwavering political stand and excellent professional ability: Teachers are crucial for ideology construction. Teacher of ideological and political theory course is brand spokesman of Marxist ideology, the quality of whom decides the effectiveness of ideological security education. At present, universities should strengthen the direct leadership of ideological and political theory course teaching. Teaching and scientific research funds should be allocated to train teachers in ideological and political theory course into genuine leader of Marxist ideology.

2) Build a professional counselor team: Counselors are "life coach" of university students and the backbone of ideological security education, irreplaceable in education. Universities must select and train counselors, provide condition and platform as well as income guarantee for them, strengthening the sense of honor, responsibility and mission of counselors to guide healthy growth of students.

3) Build a red student association team knowing the theory and how to publicize: Party and youth league organizations are important to maintain ideological security and carry out ideological and political education on college students. Universities should support association of theoretical study, instruct and grasp the correct direction. Red student association should be guided to design and organize cultural activities on campus related to ideology and politics, science and technology and cultural recreation as well as sports with rich content, novel form and strong attraction, edifying students' thoughts and feelings, enriching spiritual life and sublimating moral realm.

\section{All Sectors of Universities Should Make Concerted Efforts to Strengthen Ideological Management}

All sectors and colleges in universities should work jointly to pay high attention to ideology work. Meanwhile, the whole society should unite to build new situation of ideological publicity work in universities.

1) Strengthen the management of classroom and lecture room: Mainstream ideology education on university students is mainly carried out through classroom education. Mainstream ideological education on citizens must be realized no matter for socialist country, capitalist country, ruling class or the ruling party. Our country is socialist country. It must adhere to Marxism and its theoretical achievements in China. Ideological and political theory course must base on physical truth of China, innovate in Chinese theory and tell Chinese stories vividly, guiding students' divergent thinking to transfer from "ask me to learn" to "I want to learn". The theoretical system of socialism with Chinese characteristics should be "taught in class". Meanwhile, lecture, forum and academic seminar are important for professors and experts to spread knowledge, teachers and students to broaden horizon. Sound and normative approval system must be built to ensure the political appeal of lectures and forums, preventing the spread of non-Marxism.

2) Strengthen campus media management: General Secretary Xi Jinping proposes "strengthen internet thinking, insist integral development of traditional and new media to complement each other's advantages and base on advanced 
technology and content construction, to promote the deep integration of traditional and new media in content, channel, platform, operation and management". [6] Innovative means and mechanisms are needed to strengthen mainstream ideology construction, realizing integrative development of media in universities. According to the Opinion, network platform construction should be strengthened, promoting digitalization construction of school newspaper and magazine, creating famous network website close to learning and life of teachers and students, building network propaganda team consisting of students and young excellent teachers, demonstrative website of ideological and political education resource, student subject education website and network interactive community. Besides, the construction of network new media should be promoted, including blogs of counselors and teachers of ideological and political theory course, class weibo and weibo of school affairs as well as WeChat Subscription number of the campus.

3) Strengthen management of campus culture: University culture is the spiritual pillar of a university, the sublimation of knowledge, ability and personality, embodying academic tradition and spiritual connotation of a school, school- running idea and characteristics and guiding value pursuit and behavior of teachers and students. Therefore, the ideology work should cultivate good university culture. At present, the primary task of universities is to construct university culture with inheritance and innovation of culture and Chinese characteristics, embodying demands of the time. The cultivation and development of university culture should combine with inheritance of traditional Chinese culture, reflecting demands and characteristics of the time, let socialist core values become common faith of teachers and students through China dream.

\section{Universities Should Build A Long-term Mechanism of Ideological Security Management}

Ideology relates to the flag, road and national political security. Facing new situation and task, universities should construct mechanism and improve the controlling force of ideological security work.

1) Build the leadership mechanism of ideological security: Party committee should be responsible for ideological security, building the working mechanism managed by party committee, propaganda and related departments as well as college of Marxism, forming ideology work pattern of cooperation, effective management and powerful guarantee.

2) Build the risk prevention mechanism of ideological security: Prevention mechanism, discovery mechanism, information reporting mechanism and control mechanism should be built for ideological security risks. Control media and don't give way to wrong thoughts, ensure each teacher can provide healthy and positive knowledge, and internet website and media in school can spread useful information.

3) Build the emergency handling mechanism of ideological security: Universities should base on physical truth to build early warning and emergency handling mechanism of ideological security, the "thorough vertical and horizontal" emergency plan system, make power and responsibility of department, unit and people clear and standardize the procedure to handle with emergency. Once emergencies or accidents happen, contingency plan should be started to respond scientifically, orderly and effectively and control the situation furthest.

4) Build the condition assurance mechanism of ideological security: Combine reinforcement of ideological and theoretical construction with solution of ideological issues and strengthen humanistic care and psychological counseling and building defense line of mentality. Increase input in manpower, material resources and financial resources. Furthermore, ideological and political and new media work team with high level and quality should be built to provide manpower resource for ideological security construction in the new period.

5) Build the responsibility assigning mechanism of ideological security: The main body and object, basis and causes of accountability system, methods, procedures and mechanisms should be determined in responsibility investigation, including specific punishment measures.

\section{CONCLUSION}

To sum up, although the ideological security in universities of our country is controllable, because universities are not only the main base of ideological work but also the place for research on Marxism and cultivation of builders and successors for socialism with Chinese characteristics, it is necessary to pay high attention to ideological security, adhere to "leadership of the Party", knowing their responsibility in defend Chinese territory, responsible for any matter concerned with the post, and performing duties whole-heartedly. Meanwhile, insist "keeping pace with the times", endeavor to solve new problems and contradictions; deal with relations between "unification" and "diversification" and absorb positive results of western culture, resisting "westernization and differentiation", insisting and developing Marxism, etc. The ideological security work in universities should be implemented from duty fulfillment, team construction and position management as well as mechanism construction.

\section{REFERENCES}

[1] Xi Jinping Stresses Holding Overall Situation from the Angle of Great Event to Propagate Ideology on National Propaganda and Ideological Work Conference [N], People's Daily, Aug.21, 2013.

[2] The eighth volume of Selections of Marx and Engels, People's Publishing House, 2009 edition, page 170.

[3] Xi Jinping Stressed Holding Overall Situation from the Angle of Great Event to Propagate Ideology on National Propaganda and Ideological Work Conference [N], People's Daily, Aug.21, 2013.

[4] Mei Rongzheng. University Construction Should Adhere to Socialism with Chinese Characteristics [J], Red Flag Manuscript, Feb.2015.

[5] Mao's Collected Works, People's Publishing House, the second volume of 1993 edition, page 435 . 
[6] Important Address of General Secretary Xi Jinping on Network Security and Informatization Conference Causes Intensive Response [N], People's Daily, Apr.21, 2016.

[7] http://education.news.cn/2015-01/19/c 1114051345.htm, Opinions on Further Strengthening and Improving the Ideological Publicity Work of Universities in the New Situation Issued by General Office of the CPC Central Committee and General Office of the State Council, xinhuanet, Jan.19, 2015.

[8] Wang Xiaoxi, Huang Chenchen. Discussion on the Establishment of Speaking Right of China Dream in Young University Student Groups under the Impact of Ethos [J], Journal of Ideological and Theoretical Education, Feb.2016. 